\title{
The efficacy and safety of combination therapy with atorvastatin and tacrolimus in heart transplant recipients*
}

\author{
Blanka Skalická, Ivan Málek, Yevheniya Vymětalová, Lenka Hošková, Mariana Podzimková, Josef Kautzner
}

Department of Cardiology, Institute for Clinical and Experimental Medicine, Prague, Czech Republic

Skalická B, Málek I, Vymětalová Y, Hošková L, Podzimková M, Kautzner J (Department of Cardiology, Institute for Clinical and Experimental Medicine, Prague, Czech Republic). The efficacy and safety of combination therapy with atorvastatin and tacrolimus in heart transplant recipients. Cor Vasa 2008;50(10):368-372.

Background: HMG-CoA inhibitors are a common part of standard drug regimen after orthotopic heart transplantation (OHTx). On the other hand, they are potentially dangerous as they could interact with cyclosporin A (CsA). The aim of this study was to evaluate the efficacy and safety of combination therapy with atorvastatin and tacrolimus (TAC) in heart transplant recipients.

Methods: We followed a group of 31 OHTx patients with repeatedly documented plasma levels of total cholesterol above $5.5 \mathrm{mmol} / \mathrm{L}$ while on fluvastatin therapy. CsA was the main immunosuppressive drug. The patients were subsequently switched to a combination of TAC and atorvastatin at a starting dose of $20 \mathrm{mg}$. Four patients had to discontinue this therapy due to adverse events. The remaining 27 OHTx patients remained on follow-up. Clinical assessment with blood tests was performed one month and four months after changing the drug regimen. A subgroup of 19 patients had additional follow-up assessment after seven months of therapy.

Results: Neither myalgia nor an increase in plasma creatine kinase levels were observed. Total cholesterol levels decreased significantly after the first month of treatment $(6.06 \pm 0.89 \mathrm{mmol} / \mathrm{L}$ vs. $4.74 \pm 0.70 \mathrm{mmol} / \mathrm{L} ; p<0.0001)$. A similar trend was observed for LDL-cholesterol and apolipoprotein-B. The therapeutic effect remained stable throughout follow-up.

Conclusions: In patients after OHTx, switching to a combination of TAC and atorvastatin resulted in a significant decrease in cholesterol, LDL-cholesterol and apolipoprotein-B levels.

Key words: Atorvastatin - Dyslipidemia - Heart transplantation - Statins - Tacrolimus

Skalická B, Málek I, Vymětalová Y, Hošková L, Podzimková M, Kautzner J (Klinika kardiologie, Institut klinické a experimentální medicíny, Praha, Česká republika). Účinnost a bezpečnost kombinované léčby atorvastatinem a tacrolimem u pacientů po transplantaci srdce. Cor Vasa 2008;50(10):368-372.

Úvod: Inhibitory HMG-CoA jsou běžnou součástí standardního léčebného protokolu po ortotopické transplantaci srdce (OHTx). Na druhé straně je jejich použití potenciálně nebezpečné vzhledem k jejich interakci s cyklosporinem A (CsA). Cílem této studie bylo zhodnotit účinnost a bezpečnost kombinované léčby atorvastatinem a tacrolimem (TAC) u pacientů po transplantaci srdce.

Metody: Sledovali jsme skupinu 31 pacientů po OHTx s opakovaně dokumentovanými plazmatickými koncentracemi celkového cholesterolu vyššími než $5,5 \mathrm{mmol} / 1$ při současném podávání fluvastatinu. Hlavním imunosupresivem byl CsA. Následně byli pacienti převedeni na kombinaci TAC a atorvastatinu se zahajovací dávkou 20 mg. Pro nežádoucí účinky bylo nutno u čtyř pacientů tuto léčbu vysadit. Dále bylo sledováno zbývajících 27 pacientů po OHTx. Klinické vyšetření včetně vyšetření krve bylo provedeno jeden měsíc a čtyři měsíce po změně léčebného protokolu. U podskupiny 19 pacientů bylo provedeno kontrolní vyšetření i po sedmi měsících.

Výsledky: Nebyl zjištěn ani jeden případ myalgie nebo zvýšení koncentrace kreatinkinázy v plazmě. Po prvním měsíci léčby došlo ke statisticky významnému snížení koncentrace celkového cholesterolu $(6,06 \pm 0,89 \mathrm{mmol} / 1$ oproti 4,74 \pm 0,70 mmol/1; $p<0,0001)$. Podobný trend byl pozorován u LDL-cholesterolu a apolipoproteinu-B. Účinky léčby byly po celou dobu sledování stabilní.

Závěry: U nemocných po OHTx vedlo převedení na kombinaci TAC a atorvastatinu ke statisticky významnému snížení koncentrací celkového cholesterolu, LDL-cholesterolu a apolipoproteinu-B.

Klíčová slova: Atorvastatin - Dyslipidémie - Transplantace srdce - Statiny - Tacrolimus

Address: Blanka Skalická, MD, Institute for Clinical and Experimental Medicine, Vídeňská 1958/9, 14021 Prague 4, Czech Republic, e-mail: Blanicka.D@seznam.cz 
Dyslipidemia is a frequent metabolic disorder in patients after orthotopic heart transplantation (OHTx). Its incidence reaches $60-80 \% .^{(1)}$ Pathophysically, dyslipidemia is involved in the development of graft vascular disease (GVD) which is the most common cause of death in transplant recipients in the long run. ${ }^{(2)}$ Therefore, lipid-lowering therapy must be particularly aggressive in these patients.

At present, 3-hydroxy-3-methylglutaryl coenzyme A (HMG-CoA) reductase inhibitors - statins - are the critical component of standard medication after OHTx. However, selection of individual drugs from this group is limited because of the high risk of interaction with cyclosporin A (CsA). Typically, such an interaction results in myositis and rhabdomyolysis. ${ }^{(3,4)}$ To minimize the risk, fluvastatin is frequently used due to its unique metabolism. ${ }^{(5)}$ In addition, the dose of the drug is carefully adjusted and plasma creatine kinase levels are monitored. On the other hand, the drug has limited efficacy in some patients.

Previous studies have shown that atorvastatin is more effective than other lipid-lowering agents in reducing total cholesterol and triglyceride levels. ${ }^{(6-8)}$ However, a combination of atorvastatin and CsA could be dangerous because of the higher risk of interaction. ${ }^{\left({ }^{8}\right.}$ Less is known about the efficacy and safety of concomitant use of atorvastatin and tacrolimus (TAC). Pharmacokinetically, the addition of TAC did not alter atorvastatin pharmacokinetics. ${ }^{(9)}$ The aim of this study was to access the efficacy and safety of combination therapy with atorvastatin and TAC in OHTx recipients.

\section{MATERIALS AND METHODS}

The study population consisted of a group of 31 OHTx patients ( 21 men, 10 women, age $53.9 \pm 10$ years) with repeatedly detected plasma levels of total cholesterol above $5.5 \mathrm{mmol} / \mathrm{L}$ during the last 6 months along with fluvastatin therapy (mean dose, $69 \pm 19 \mathrm{mg}$ ).

The patients were followed up for seven months. Table I shows the clinical characteristics of the whole cohort. All patients received CsA in combination with azathioprine ( $n=7)$ or mycophenolate mofetil $(n=22)$ and prednisone $(\mathrm{n}=29)$.

Exclusion criteria included significant renal insufficiency with creatinine above $250 \mu \mathrm{mol} / 1$, liver insufficiency or active liver disease, hypersensitivity to statins, previous administration of TAC or atorvastatin (after OHTx), acute infection, acute rejection and noncompliance of the patient.

All patients were thoroughly informed about monitoring and signed informed consent. The study protocol conforms to the ethical guidelines of the 1975 Declaration of Helsinki as reflected in an a priori approval by the institution's human research committee. After baseline laboratory analysis, the patients were switched from CsA to TAC according to the following protocol: the last CsA dose was administered in the evening and TAC was started the next morning at a dose of $0.1-0.15 \mathrm{mg} / \mathrm{kg}$ twice daily. Patients were instructed to report any unusual muscle soreness, nausea, vomiting or prolonged diarrhea.
Table I

Patients' characteristics

\begin{tabular}{lll}
\hline \hline Number & 31 & \\
\hline Age & $53 \pm 10$ years \\
\hline Sex & 10 women \\
& 21 men \\
\hline Baseline disease & IHD & $(\mathrm{n}=13)$ \\
& DCMP $\quad(\mathrm{n}=17)$ \\
\hline Donor age & RHD & $(\mathrm{n}=1)$ \\
\hline Time since OHTx & $37 \pm 13$ years \\
\hline Diabetes mellitus & $66 \pm 42$ months \\
\hline Immunosuppression & 6 & $(\mathrm{n}=31)$ \\
& CsA & $(\mathrm{n}=7)$ \\
& AZA & MMF \\
\hline \hline
\end{tabular}

IHD - ischemic heart disease, DCMP - dilated cardiomyopathy, RHD - rheumatic heart disease, CsA - cyclosporin A, AZA - azathioprine, MMF - mycophenolate mofetil

Hematologic parameters, fasting glucose, serum creatinine, blood urea nitrogen, creatine kinase, creatine kinase muscle-brain fraction (CK-MB), bilirubin, liver enzymes aspartate aminotransferase (AST), alanine aminotransferase (ALT), $\gamma$-glutamyltransferase (GMT), alkaline phosphatase (ALP), lactic dehydrogenase (LDH), total cholesterol, high-density lipoprotein cholesterol (HDL-C), low-density lipoprotein cholesterol (LDL-C), triglycerides (TG), apolipoprotein-A (apo-A), and apolipoprotein-B (apo-B) were assessed.

After a period of 7-10 days, TAC levels were determined with dose adjustment to obtain average levels between 5 and $15 \mathrm{nmol} / \mathrm{L}$ (throughout the post-transplant period). At the same time, fluvastatin was replaced by atorvastatin at a starting dosage of $20 \mathrm{mg}$. Clinical status and laboratory tests were assessed at one month and four months after switching the drugs. A subgroup of 19 patients was evaluated again at seven months.

Data are expressed as a mean \pm SD. Analysis of variance for repeated measures was used for statistical analysis, with values of $p<0.05$ considered significant.

\section{RESULTS}

Four patients were excluded from the follow-up during the first month. Three patients discontinued TAC because of the following reasons: serious diarrhea, progressive elevation of serum creatinine levels, and psychic disorders. One patient stopped atorvastatin because of a sore throat. No myalgia or elevation of creatine kinase levels were observed in the remaining cohort. Nevertheless, the majority of these patients experienced some diarrhea after switching to TAC. Diarrhea subsided in all after the dose adjustment.

At one month, atorvastatin significantly reduced total cholesterol levels $(6.06 \pm 0.89 \mathrm{mmol} / \mathrm{L}$ vs. $4.74 \pm$ $0.70 \mathrm{mmol} / \mathrm{L}$ after conversion; $p<0.0001$ ), as well as LDL-cholesterol levels $(3.21 \pm 0.77$ vs. $2.13 \pm$ $0.67 \mathrm{mmol} / \mathrm{L} ; p<0.0001)$, plasma triglycerides $(2.48 \pm$ 1.15 vs. $1.81 \pm 0.83 ; p<0.0001)$ and Apo-B $(1.07 \pm$ 
0.22 vs. $0.76 \pm 0.20 \mathrm{~g} / \mathrm{L} ; p<0.0001)$. By contrast, levels of HDL-cholesterol, Apo-A, creatinine and liver transaminases changed only non-significantly (Table II). At four months, the levels of total cholesterol, LDL-cholesterol and Apo-B remained decreased. Total cholesterol levels decreased below $5.5 \mathrm{mmol} / \mathrm{L}$ in $88.9 \%$ of patients after one month, and in $77.8 \%$ of patients after four months. The dose of atorvastatin at four months reached $21 \pm 5 \mathrm{mg}$. In two patients, the dose of atorvastatin had to be increased to 30 and $40 \mathrm{mg}$. In another patient, the dose was decreased to $10 \mathrm{mg}$ because of weight loss. During the treatment period, decreases in urea $(10.32 \pm 3.46$ vs. $9.04 \pm$ $2.94)$ and hematocrit $(0.38 \pm 0.03$ vs. $0.37 \pm 0.03)$ reaching statistical significance were observed. However, this change was considered clinically irrelevant.

The subgroup of 19 patients was evaluated again at 7 months and this follow-up examination revealed a sustained decrease in total cholesterol, TG, LDL-cholesterol and Apo-B levels (Figure 1). No significant change in liver tests was noted. Although platelet count decreased significantly $(240.40 \pm 55.65$ vs. $223.07 \pm 57.14$ ), the change was again considered clinically irrelevant.

\section{DISCUSSION}

Results of this study can be summarized as follows: /1/ prospective follow-up demonstrated clinical efficacy of switching from fluvastatin to atorvastatin in terms of sustained lowering of cholesterol, LDL-cholesterol and Apo B levels, /2/ the combination of atorvastatin with tacrolimus after replacing CsA proved to be safe with no occurrence of myositis or rhabdomyolysis.

Treatment of dyslipidemia is one of the most critical components of comprehensive care after OHTx. The prevalence of dyslipidemia after OHTx is in the range of $60-80 \%$. Most importantly, cholesterol levels rise relatively early ( 1 to 6 months) after transplantation. ${ }^{(1)}$ Among risk factors, both daily and cumulative prednisone dosage, body mass index (BMI) $>25 \mathrm{~kg} / \mathrm{m}^{2}$, and a pre-transplant diagnosis of coronary artery disease appear to be the most important ones. ${ }^{(10)}$ There is a correlation between increased cholesterol and triglyceride levels and the development of GVD as the main factor limiting long-term survival after OHTx. $^{(2,11,12)}$

Two prospective, randomized clinical trials have demonstrated high efficacy of statins in reducing

Table II

Laboratory tests and changes after switching patients to atorvastatin and tacrolimus after 4 months

\begin{tabular}{|c|c|c|c|c|}
\hline Variables & Base line & After one month & After four months & $\mathbf{N}$ \\
\hline Total cholesterol (mmol/L) & $6.06 \pm 0.89$ & $4.74 \pm 0.70^{* * *}$ & $4.82 \pm 0.82^{* * *}$ & 27 \\
\hline TG (mmol/L) & $2.48 \pm 1.15$ & $1.81 \pm 0.83^{* * *}$ & $2.0 \pm 1.28^{*}$ & 27 \\
\hline HDL-cholesterol (mmol/L) & $1.78 \pm 0.55$ & $1.76 \pm 0.52$ & $1.66 \pm 0.64$ & 21 \\
\hline LDL-cholesterol (mmol/L) & $3.21 \pm 0.77$ & $2.13 \pm 0.69^{* * *}$ & $2.27 \pm 0.66^{* * *}$ & 18 \\
\hline Apo-A (mmol/L) & $1.82 \pm 0.33$ & $1.86 \pm 0.48$ & $1.86 \pm 0.50$ & 20 \\
\hline Apo-B (mmol/L) & $1.07 \pm 0.2$ & $0.76 \pm 0.19^{* * *}$ & $0.76 \pm 0.19^{* * *}$ & 21 \\
\hline Glucose (mmol/L) & $5.52 \pm 1.5$ & $5.52 \pm 0.82$ & $5.43 \pm 1.5$ & 26 \\
\hline Creatinine $(\mu \mathrm{mol} / \mathrm{L})$ & $135.22 \pm 39.77$ & $130.76 \pm 35.08$ & $128.96 \pm 31.09$ & 27 \\
\hline Urea $(\mathrm{mmol} / \mathrm{L})$ & $10.32 \pm 3.46$ & $9.04 \pm 2.94^{* *}$ & $8.71 \pm 3.04^{* *}$ & 27 \\
\hline Creatine kinase ( $\mu$ kat/L) & $1.52 \pm 1.05$ & $1.35 \pm 1.05$ & $1.68 \pm 1.30$ & 26 \\
\hline CK-MB ( $\mu$ kat/L) & $0.24 \pm 0.08$ & $0.28 \pm 0.07$ & $0.28 \pm 0.07$ & 19 \\
\hline LDH ( $\mu$ kat/L) & $3.34 \pm 1.24$ & $3.14 \pm 0.60$ & $3.33 \pm 0.75$ & 20 \\
\hline Total bilirubin $(\mu \mathrm{mol} / \mathrm{L})$ & $15.37 \pm 8.37$ & $12.84 \pm 7.44$ & $14.46 \pm 8.04$ & 27 \\
\hline AST ( $\mu$ kat/L) & $0.4 \pm 0.17$ & $0.36 \pm 0.14$ & $0.39 \pm 0.19$ & 27 \\
\hline ALT ( $\mu$ kat/L) & $0.43 \pm 0.24$ & $0.41 \pm 0.16$ & $0.49 \pm 0.24$ & 27 \\
\hline ALP ( $\mu$ kat/L) & $0.36 \pm 0.53$ & $1.30 \pm 0.51$ & $1.30 \pm 0.51$ & 26 \\
\hline GMT ( $\mu$ kat/L) & $1.29 \pm 1.62$ & $1.18 \pm 1.31$ & $1.51 \pm 1.76$ & 27 \\
\hline Erythrocytes (ele $\times 10^{12}$ ) & $4.36 \pm 0.69$ & $4.19 \pm 0.49$ & $4.22 \pm 0.86$ & 27 \\
\hline Hemoglobin (g/L) & $137.85 \pm 13.68$ & $134.66 \pm 11.81$ & $138.33 \pm 14.39$ & 27 \\
\hline Hematocrit & $0.38 \pm 0.03$ & $0.37 \pm 0.03^{*}$ & $0.38 \pm 0.04$ & 27 \\
\hline Thrombocytes $\left(\right.$ ele $\left.\times 10^{9}\right)$ & $240.40 \pm 55.65$ & $237.40 \pm 63.99$ & $223.07 \pm 57.14^{*}$ & 27 \\
\hline Leukocytes (ele × 109) & $6.86 \pm 1.62$ & $6.82 \pm 1.40$ & $7.12 \pm 1.58$ & 27 \\
\hline Lymphocytes (ele $\times 10^{9}$ ) & $1.66 \pm 0.63$ & $1.55 \pm 0.57$ & $1.55 \pm 0.64$ & 27 \\
\hline Neutrophils (ele $\times 10^{9}$ ) & $4.40 \pm 1.30$ & $4.47 \pm 1.08$ & $4.64 \pm 1.25$ & 27 \\
\hline
\end{tabular}

Statistical results are related to baseline $\left({ }^{* * *}-p<0.0001 ;{ }^{* *}-p<0.01 ; *-p<0.05\right)$ 


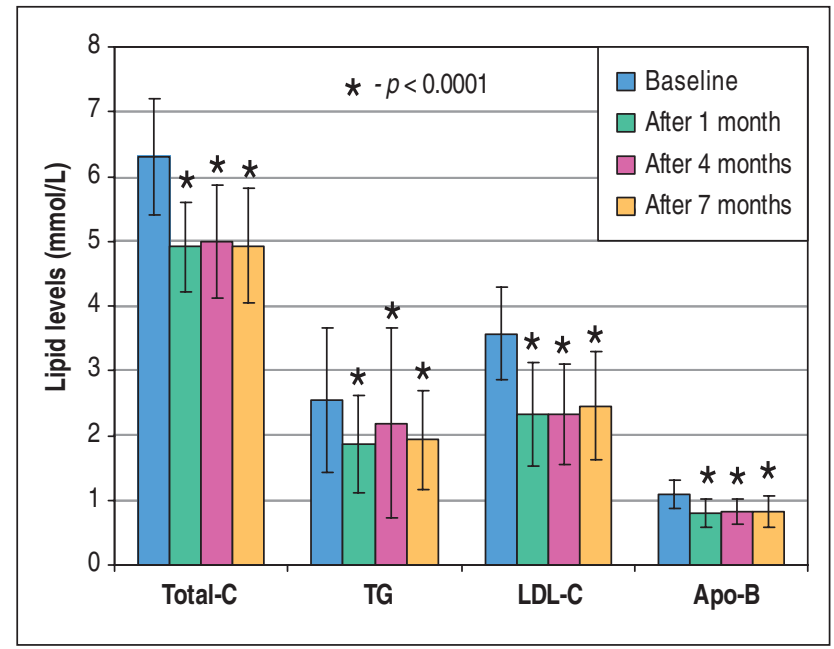

Figure 1 Changes in lipid levels after switching to tacrolimus and atorvastatin after 7 months $(\mathrm{n}=19)$. Statistical results are related to baseline $(*-p<0.0001)$

LDL-cholesterol and their beneficial effect on GVD and survival. Kobashigawa et al. ${ }^{(13)}$ randomized 97 patients early after OHTx to pravastatin $(n=47)$ or placebo for 12 months. The pravastatin group showed significantly lower total cholesterol levels $(193 \pm 36$ vs. $248 \pm 49 \mathrm{mg} / \mathrm{dl}, p<0.001)$, better survival rate (94\% vs. $78 \%, p=0.025)$, lower incidence of GVD (by angiography and at autopsy), and less progression in intimal thickening and intimal index (by intravascular ultrasound). Moreover, pravastatin was shown to reduce the prevalence of acute rejection and the activity of natural killer cells. This study continued and 10-year follow-up data have been reported. ${ }^{(14)}$ Eighty-one percent of controls were placed on statin therapy in the 10-year follow-up. Still, the 10-year survival rate remained significantly better in pravastatin patients (68\% vs. $48 \%, p=0.026)$ and freedom from angiographic GVD and/or death was greater in this group ( $43 \%$ vs. $20 \%, p=0.0009)$. In the second study, Wenke et al. ${ }^{(15)}$ compared treatment with simvastatin $(n=35)$ and diet therapy $(n=37)$. The simvastatin group showed significant improvement in the 4-year survival rate (88.6\% vs. $70.3 \%)$, lower incidence of GVD by angiography, less intimal thickening, and a lower intimal index by intravascular ultrasound. In an extension of this study, most patients in both groups received statins after 4 years. As long as after 11 years, survival rate was significantly better in the simvastatin group and the incidence of GVD was also significantly lower. ${ }^{(16)}$ The above landmark studies provided evidence about the value of statin therapy after OHTx and about the need for its initiation early after transplantation.

Currently, fluvastatin is one of the most often used statins after OHTx due to its safety. However, the efficacy of fluvastatin appears to be rather modest, especially in some patients. In this respect, atorvastatin is more effective than other lipid-lowering agents in reducing total cholesterol and triglyceride levels. ${ }^{(6-8)}$ The problem with the use of atorvastatin in the post-transplant population appears to be interaction with CsA. There is evidence that the use of even moderate doses of atorvastatin in CsA-treated patients can result in myositis in some. ${ }^{(8)}$ This observation is consistent with experimental studies showing a significant increase in the plasma levels of statins after exposure to CsA. ${ }^{(17)}$ The interaction is due to the competitive inhibitory effect of CsA on drug metabolism by cytochrome P450 3A4 (CYP3A4) and efflux by drug transporter P-glycoprotein. Interestingly, TAC does not seem to alter atorvastatin pharmacokinetics as documented in a study with 13 healthy volunteers. ${ }^{(9)}$ On the contrary, concomitant administration of CsA led to a 15-fold increase in the plasma levels of atorvastatin. Our study was designed to evaluate patients after OHTx. Although atorvastatin levels were not determined in this study, the safety record of the combination of atorvastatin and TAC supports the above observation. Therefore, this combination can be recommended for the treatment of dyslipidemia after OHTx, especially after other statins have failed.

\section{STUDY LIMITATIONS}

This study has several limitations. First, the number of patients was relatively small and follow-up was short. Second, since TAC has been reported to exert a lipid-lowering effect, ${ }^{18)}$ this study is unable to determine the magnitude of the lipid-lowering effect atorvastatin as compared with TAC. Third, despite the significant decrease in cholesterol and LDL-cholesterol levels, very few patients reached the levels recommended by guidelines on lipid-lowering therapy for a high-risk group. ${ }^{(19)}$ Total cholesterol levels below $4.0 \mathrm{mmol} / \mathrm{L}$, LDL-cholesterol levels $<2.0 \mathrm{mmol} / \mathrm{L}$, and Apo-B $<0.8 \mathrm{~g} / \mathrm{L}$ were achieved in only $18.5 \%$ of the patients after 4 months, and in only $5.3 \%$ of patients after 7 months. Increasing the dose of atorvastatin can be expected to be more effective.

\section{CONCLUSIONS}

Management of dyslipidemia after OHTx may be difficult because of medical interactions. Our pilot study demonstrated the clinical efficacy of switching patients from fluvastatin to atorvastatin after replacing CsA with TAC. This combination has proved to be safe with no occurrence of myositis or rhabdomyolysis.

\section{REFERENCES}

1. Miller LW, Schlant RC, Kobashigawa J, Kubo S, Renlund DG. 24th Bethesda conference: Cardiac transplantation. Task Force 5: complications. J Am Coll Cardiol 1993; 22:41-54

2. Keogh AM, Valantine HA, Hunt SA, et al. Impact of proximal or midvessel discrete coronary artery stenoses on survival after heart transplantation. J Heart Lung Transplant 1992;11:892-901.

3. Ballantyne CM, Corsini A, Davidson MH, et al. Risk for myopathy with statin therapy in high-risk patients. Arch Intern Med 2003;163:553-64.

4. Omar MA, Wilson JP. FDA adverse event reports on statin-associated rhabdomyolysis. Ann Pharmacother 2002;36:288-95.

5. Spinarova L, Toman J. Fluvastatin in patients after transplantation of the heart. Vnitř Lék 1998;44:13-6.

6. Jones P, Kafonek S, Laurora I, Hunninghake D, for the CURVES Investigators. Comparative dose efficacy study 
of atorvastatin versus simvastatin, pravastatin, lovastatin, and fluvastatin in patients with hypercholesterolemia. (The CURVES Study). Am J Cardiol 1998;81: 582-7.

7. Magnani G, Carinci V, Magelli C, Potena L, Reggiani LB, Branzi A. Role of statins in the management of dyslipidemia after cardiac transplant: randomized controlled trial comparing the efficacy and the safety of atorvastatin with pravastatin. J Heart Lung Transplant 2000;19:710-5.

8. Patel DN, Pagani FD, Koelling TM, et al. Safety and efficacy of atorvastatin in heart transplant recipients. J Heart Lung Transplant 2002;21:204-10.

9. Lemahieu WP, Hermann M, Asberg A, et al. Combined therapy with atorvastatin and calcineurin inhibitors: no interactions with tacrolimus. Am J Transplant 2005;5: 2236-43.

10. Rudas L, Pflugfelder PW, McKenzie FN, Menkis AH, Novick RJ, Kostuk WJ. Serial evaluation of lipid profiles and risk factors for development of hyperlipidemia after cardiac transplantation. Am J Cardiol 1990;66:1135-8.

11. Orbaek Andersen H. Heart allograft vascular disease: an obliterative vascular disease in transplanted heart. Atherosclerosis 1999;142:243-63.

12. Escobar A, Ventura HO, Stapleton DD, et al. Cardiac allograft vasculopathy assessed by intravascular ultrasonography and nonimmunologic risk factors. Am J Cardiol 15;74:1042-6.

13. Kobashigawa JA, Katznelson S, Laks H, et al. Effect of pravastatin on outcomes after cardiac transplantation. N Engl J Med 1995;333:621-7.
14. Kobashigawa JA, Moriguchi JD, Laks H, et al. Ten-year follow-up of a randomized trial of pravastatin in heart transplant patients. J Heart Lung Transplant 2005;24: 1736-40.

15. Wenke K, Meiser B, Thiery J, et al. Simvastatin reduces graft vessel disease and mortality after heart transplantation: a four-year randomized trial. Circulation 1997;96: 1398-402.

16. Wenke K, Meiser B, Thiery J, Reichart B, et al. Impact of simvastatin therapy after heart transplantation: an 11-year prospective evaluation. Herz 2005;30:431-2.

17. Hermann M, Asberg A, Christensen H, Holdaas H, Hartmann A, Reubsaet JL. Substantially elevated levels of atorvastatin and metabolites in cyclosporine-treated renal transplant recipients. Clin Pharmacol Ther 2004;76:388-91.

18. Taylor DO, Barr ML, Radovancevic B, et al. A randomized, multicenter comparison of tacrolimus and cyclosporine immunosuppressive regimens in cardiac transplantation: decreased hyperlipidemia and hypertension with tacrolimus. J Heart Lung Transplant 1999;18:336-45.

19. Vaverková H, Soška V, Rosolová $H$, et al. Czech Atherosclerosis Society guidelines for the diagnosis and treatment of dyslipidemia in adults. Cor Vasa 2007;49: K 73-K 86.

Received 12 May 2008

Revision accepted 29 June 2008 